\title{
Bunt w ramach pamięci. "Solidarnośćc", rewolucja, powstanie
}

Przemysław Czapliński

TEKSTY DRUGIE 2016, NR 6, S. 204-225

DOI: 10.18318/td.2016.6.11

„Nie o krótką pamięć tu chodzi, ale o kolejną szansę?"1

Krzysztof Siwczyk

$\mathbf{Z}$ ajmujemy się pamięcią, ponieważ sądzimy - nie bez podstaw - że tkwią w niej zaczepy tożsamości jednostkowej i zbiorowej. Pamięć nie dotyczy tylko przeszłości, miesza się bowiem z teraźniejszymi doznaniami, nakładając na świat widziany i doświadczany wzorce przeniesione z przeszłości. Ingeruje w postrzeganie świata, wpływając na nasze uczestnictwo w życiu i na projektowaną przyszłość. Badać pamięć to sięgać do matryc sensu, które współdecydują o sposobie stawiania pytań skierowanych ku aktualnemu światu, to szukać obrazów i opowieści, które nadal wywierają wpływ. Pamięć jest nie tyle depozytariuszem historii, co współwytwórcą każdej teraźniejszości.

Nie jest to jednak łatwy przedmiot badań. Z pozoru miękko broni dostępu do swoich archiwów, objawiając

\section{Przemysław}

Czapliński - historyk literatury XX i XXI wie$\mathrm{ku}$, eseista, tłumacz, krytyk literacki; kierownik specjalności krytycznoliterackiej. Ostatnie publikacje: Polska do wymiany (2009), Resztki nowoczesności (2011), Poruszona mapa (2016).

Przedmiot badań: literatura (polska) i problemy późnej nowoczesności. Kurator cyklów dyskusyjnych - ostatnio: „Bioklasy: segregacje i sojusze" (2016), "Prognozowanie teraźniejszości" (2016).

1 K. Siwczyk [2003] Zdania z treściq̨. Cyt. wg wydania: tegoż List otwarty 1995-2005, Biuro Literackie, Wrocław 2005, s. 202. 
się we wszystkim - w zeznaniach i listach, w dziełach sztuki i codziennej rutynie, pomnikach i nazwach ulic, w zbiorowych aktach założycielskich i destrukcyjnych. Choć jednak człowiek nie może wypowiedzieć niczego, co nie byłoby w pamięci zadłużone i nie może uczynić niczego, co z pamięcią nie byłoby sprzężone, to potrafi zakłamać bądź zakryć każdą pamięć. Ona sama jest bezkształtna i bezbronna, potrzebuje więc wypowiedzeń, a te przechodzą przez rozmaite sita kultury i filtry polityki. Pamięć zaświadczona - a o niej będzie tu mowa - nie sumuje się w żadną całość, składa się raczej z treści ważnych niż prawdziwych, a funkcjonuje nie jako statyczne archiwum, lecz raczej jako nieustanna aktywność, forma działania, ustawicznego negocjowania znaczeń prowadzonego przez podmiot z samym sobą i ze zbiorowością, w której żyje. Pamięć nie jest zatem magazynem kompletnej wersji przeszłości, nie jest obiektywna i nie jest nieruchoma. Te trzy jej właściwości objawiają się ze szczególną mocą w momentach krytycznych życia zbiorowego. W chwilach takich społeczność spiera się o pamięć nie dlatego, by ustalić, jak było, lecz po to, by wzmocnić swoją pozycję w walce o nadawanie znaczeń teraźniejszości. Spór o przeszłość nie jest sporem o obiektywną prawdę, lecz o mit - o opowieść nadającą sens teraźniejszości.

Walka o pamięć, choćby sięgała w najgłębszą przeszłość, jest projektowaniem teraźniejszości. Kto określa pamięć - czyli kierunek, jaki pamięć wyznaczyła teraźniejszości - ten definiuje sytuację.

\section{Punkt sporny}

Artykuł Marcina Zaremby budzi uznanie spokojnym tempem archeologicznej pracy, a także, a może zwłaszcza, poszerzonym zestawem źródeł. Autor wprowadził - do tej pory nigdy chyba nieanalizowane - listy cenzurowane i/ lub konfiskowane przez urzędników. Na tej podstawie, wzmocnionej ciekawą rewindykacją PRL-owskiej kultury masowej, autor stawia tezę, że rok 1980 kumulował w sobie pamięć wszystkich wystąpień przeciw komunizmowi, a ponadto aktywował matrycę powstaniową z epok wcześniejszych.

Stwierdzenie, że w działaniach okresu „Solidarnościowego" przejawiała się pamięć o powstaniach, jest bezsprzecznie prawdziwe. Razem z tą prawdziwością uznać musimy za słuszne przekonanie, że pamięć o powstaniach mogła połączyć się z działaniami „Solidarnościowymi” tylko dzięki kolejnym podstawieniom i redukcjom. W łańcuchu substytucji musiały znikać różnice między powstaniem listopadowym, styczniowym czy warszawskim a "Solidarnością", jeśli wydarzenia z lat 1980-1981 miały wystąpić jako kolejne 
ogniwo tradycji wyzwoleńczej. Zbliżyć członków związku zawodowego do powstańców można było wyłącznie za cenę uproszczeń i radykalnych pominięć. Oś podobieństwa wzięła górę nad osią ekwiwalencji.

Z tym wszystkim stwierdzenie, że w okresie „Solidarności” pojawiła się pamięć powstań, wydaje się oczywiste i niewystarczające. Jest oczywiste, jeśli uprzytomnimy sobie wielość odwołań do tradycji powstańczych. Okaże się niedostateczne, jeśli pamięć powstańczą uznamy za dominantę społeczno-polityczno-historycznej świadomości okresu „Solidarnościowego". Śmiem twierdzić, że gdyby pamięć powstań była najsilniejszym warunkiem narodzin „Solidarności”, niezależny związek zawodowy by nie powstał.

\section{Dominanta heroiczna}

Kiedy badamy pamięć uczestników „Solidarnościowego” ruchu początku lat 8o., chcemy dowiedzieć się tego, co ludzie pamiętali, ponieważ zakładamy, że miało to wpływ na jednostkowe i zbiorowe działania. Badanie dokumentów w poszukiwaniu metafor, skojarzeń, analogii i porównań, ma pomóc w zrekonstruowaniu ramy modelującej - czyli quasi-systemu, który w planie jednostkowym i zbiorowym miałby porządkować rzeczywistość, kształtując postrzeganie ówczesnej rzeczywistości i sposoby działania.

Spośród wielu metod analizy pamięci Marcin Zaremba wybrał koncepcję, która polega - tu sparafrazuję Maurice'a Halbwachsa - na rekonstruowaniu powstańczych ram pamięci. Dla francuskiego badacza, autora studium Społeczne ramy pamięci ${ }^{2}$, pamięć jednostkowa nigdy nie jest do końca jednostkowa. Wspominanie według niego jest bowiem czynnością społeczną, osadzoną w ramach pamięci, czyli „strukturach społecznych, które jednoczą nasze myślenie i dzięki którym dokonują się rekonstrukcje przeszłości"3. Jednostka pamięta zatem to, co istotne dla porozumienia w ramach mikrospołeczności, do której należy - w ramach rodziny, klasy społecznej bądź wspólnoty wyznaniowej. Pamięć jednostkowa nie tylko wypełnia się konkretnymi treściami potrzebnymi do komunikacji w relacjach społecznych, lecz także jest modelowana przez ową komunikację. Jako członkowie rodziny, klasy czy zbiorowości religijnej nabywamy konkretnych wspomnień pozwalających

2 Zob. M. Halbwachs Społeczne ramy pamięci, przeł. M. Król, PWN, Warszawa 1969; wyd. cyt.: 2008.

3 M. Halbwachs Społeczne ramy pamięci..., s. 4. 
nam zakorzenić się w grupie, a ponadto jesteśmy uwrażliwiani na jedne treści i znieczulani na inne. „To właśnie w społeczeństwie człowiek normalnie nabywa wspomnienia, rozpoznaje je i lokalizuje"4 - stwierdza Halbwachs. Pamięć i współistnienie jednostki w zbiorowości warunkują się wzajemnie i wspomagają: pamięć jednostkowa jest nośnikiem tożsamości zbiorowej, a tożsamość zbiorowa to zestaw zachowań i definicji, które zakorzeniają jednostkę. Pojedynczy człowiek pamięta nie to, co było, lecz to, co umacnia przynależność do grupy. Jeśli zmieni swoją przynależność - klasową, rodzinną, religijną - zacznie uczyć się nowej wrażliwości pamięciowej. Nie utraci wspomnień z poprzedniego etapu, lecz straci przekonanie o ważności tych wspomnień dla swojego aktualnego położenia społecznego.

Zaremba wskazał na innych badaczy - posługujących się kategoriami „wzoru kultury” (Jack Goldstone), „tradycji” (Jerzy Szacki), „zbiorowej pamięci przeszłości” (Barbara Szacka) czy „kultury historycznej”. Wszystkie te koncepcje - pisze Zaremba - "mówią o tym samym: odziedziczonym z przeszłości zestawie wartości, znaczeń, symboli, przekonań, dominującym i kształtującym społeczne, ekonomiczne, religijne i polityczne obyczaje i strategie działania"'. Oznacza to, że tradycja - w takim sensie, w jakim Halbwachs pisał o "społeczności” - jest ramą jednostkowej i zbiorowej pamięci: uczymy się pamiętać nie za sprawą bezpośredniego udziału, lecz za sprawą nieustannej repetycji dokonywanej przez zbiorowość, do której należymy; artykułujemy nie całą pamięć, lecz to, co z przeszłości pomaga nam wyznaczyć nasze miejsce w grupie i adekwatny do tego sposób postępowania.

Tak określony koncept metodologiczny jest inspirujący i zarazem wysoce zdradliwy. Autor przeanalizował zbiorową pamięć uczestników ruchu „Solidarnościowego", wydobywając z niej wspomnienia powstań narodowych, ze szczególnym uwzględnieniem powstania warszawskiego. Wyszedł przy tym z założenia, że pamięć zbiorowa - dokładnie tak, jak przekonywał Halbwachs - jest wybiórcza i stronniczo kumulatywna: pamięć taka radykalnie i bezceremonialnie wycina wszystko, co nieistotne, zachowując to, co będzie sprzyjać podtrzymaniu tożsamości zbiorowej. Takie założenie pozwala badaczowi potwierdzić inne przypuszczenie, mówiące, że społeczeństwa różnią się między sobą pod względem zachowań zbiorowych: polska społeczność

4 Tamże.

5 M. Zaremba „Im się zdaje, że zapomnimy. O nie!"Rodowody rewolucji - zob. w niniejszym numerze "Tekstów Drugich". 
jest buntownicza, inne zbiorowości zaś skłonne są raczej do negocjacji bądź posłuszeństwa. Według Marcina Zaremby źródłem zachowań dominujących w polskiej kulturze jest rama powstańcza, która eliminując zróżnicowane fragmenty przeszłości, modeluje przekaz o heroicznej postawie zbiorowej. Wytwarza to swoiste sprzężenie zwrotne: powstańczy przekaz podtrzymywany przez zbiorowość formuje pamięć jednostkową, która z ogółu doświadczeń wybiera i przechowuje fragmenty pasujące do heroicznej całości. W ten sposób Zaremba wyjaśnia, że „Solidarność” mogła się wydarzyć, ponieważ społeczeństwo po roku 1970 przywołało pamięć powstań dawnych, by w roku 1980 wzniecić nowe. Tymczasem historia lat 8o. - zwieńczona Okrąłym Stołem - zdaje się wskazywać, że nie każdy opór jest powstaniem, nie każde powstanie wyzwala wszystkich jego uczestników i że nie ma takiej tradycji, której społeczeństwo nie potrafiłoby skonstruować na nowo.

\section{Rewolucja przeciw powstaniu}

Na początku był strajk. Wybuchł w Świdniku 8 lipca 1980 roku, rozszerzył się na całą Lubelszczyznę, trwał do 25 lipca. Wywołała go ogłoszona 1 lipca zapowiedź podwyżek cen żywności. Pracownicy świdnickich Zakładów Lotniczych, lubelskiego Polmozbytu, Fabryki Maszyn Rolniczych, Fabryki Samochodów Ciężarowych, Zakładów Azotowych w Puławach, Fabryki Łożysk Tocznych w Kraśniku i wielu innych zażądali polepszenia warunków pracy i likwidacji rozmaitych przywilejów (sklepy komercyjne, sprzedaż wewnętrzna za waluty) dla rządzących i bogatszych.

Bez tej fali protestów nie byłoby „Solidarności”, choć szybkie podpisywanie porozumień z załogami nie zapowiadało dalszego ciągu. Żądania pracowników miały dwojaki charakter - ekonomiczny i polityczny, więc geneza strajku nie tkwiła w pamięci powstańczej, lecz w świadomości robotniczej. W odpowiedzi na doświadczenie biedy, beznadziei i bałaganu świadomość ta zrodziła pełne desperacji pragnienie zmiany:

Później mi koleżanka wspomniała, że rozmawiała i z innymi pracownikami i nie będziemy pracować; po prostu dłużej takiego bałaganu już być nie może, jak jest. ${ }^{6}$

Mieliśmy dosyć.?

6 I. Krzemiński Solidarność. Projekt polskiej demokracji, Oficyna Naukowa, Warszawa 1996, s. 52-53.

7 Tamże, s. 53. 
W początkowym okresie to [...] było podejście czysto emocjonalne, że coś się musi zmienić, że ktoś się wreszcie za to wziął i może będzie lepiej. Jeszcze nie wiadomo było, dlaczego ma być lepiej i kto ma to zrobić, żeby było lepiej. W każdym razie to było odczucie tylko tego typu, że powinno się coś wreszcie zmienić w kraju. ${ }^{8}$

Rewolucyjne "Tak dłużej być nie może” prowadzi zatem początkowo do strajku. Przez cały okres powojenny władze państwa komunistycznego nie dopuszczały słowa "strajk" do języka oficjalnego, wstawiając w to miejsce eufemizmy w rodzaju „przerwy/przestoje w pracy”. Zgoda na użycie słowa „strajk" równałaby się uznaniu, że relacje między pracodawcami i robotnikami w państwie socjalistycznym nadal mają charakter kapitalistyczny i polegają na przechwytywaniu wartości dodanej. Przyznanie, że strajk wybuchł w obronie godności, byłoby czymś jeszcze gorszym - równałoby się stwierdzeniu, że państwo socjalistyczne upokarza klasę, dla której powstało i w imieniu której rząd sprawuje władzę. Tymczasem u podłoża strajków legło intuicyjne zrozumienie, że w państwie socjalistycznym wyzysk ekonomiczny jest sprzężony z zaborem godności. Rację miał Józef Tischner, przez którego przemawiał wówczas duch dziejów, gdy w metaforze łączącej obie sfery określił „Solidarność” jako „bunt przeciw wyzyskowi moralnemu”"

Sformułowanie to dobrze oddaje szybki przyrost samowiedzy. Ale także odsłania jej procesualność: im sprawniej się organizowano, tym większy był przyrost samowiedzy, im precyzyjniej definiowano sytuację, tym skuteczniejsze okazywały się formy działania. W trakcie działań, ale też dzięki nim, odkrywano krok po kroku, że nic nie jest dane w całości - od języka zaczynając, na zmiennych celach kończąc. Dlatego samowiedza uczestników buntu w niewielkim stopniu korzystała z pamięci, ponieważ w pamięci nie było czegoś takiego, jak „strajk solidarny” czy „niezależny związek zawodowy”. Kluczowa

8 Tamże.

9 Zob. M. Głowiński Nowomowa tuż po Sierpniu, w: tegoż Nowomowa po polsku, Wydawnictwo PEN, Warszawa 1990, s. 96: „Nie będzie przesadą, gdy się powie, iż dzieje użyć słowa «strajk» streszczają dzieje nowomowy - zastosowanie go do wydarzeń krajowych, przełamujące jedno z tych językowych tabu, które strzeżone było z wyjątkową konsekwencją - równa się jej załamaniu. W lubelskim «Sztandarze Ludu» z 19 lipca 1980 słowo to jeszcze nie padło [...]. W przemówieniu Gierka z 18 sierpnia słowo użyte zostało raz, ale też nieśmiało, jakby z trudem, po całej serii «przerw» $\mathrm{i}$ «przestojów». Do normalnego obiegu weszło dopiero pod sam koniec sierpnia".

10 J. Tischner Etyka solidarności oraz Homo sovieticus, Znak, Kraków 1992, s. 34. 
różnica między wydarzeniami roku 1970 i roku 1980 nie została zatem wyprowadzona z pamięci, lecz pojawiła się niejako wbrew niej - jako rezultat rozpoznania niedostateczności dotychczasowych doświadczeń. Nie jest przypadkiem, że Dariusz Kobzdej, lekarz, działacz Ruchu Młodej Polski, zachęcając innych do włączenia się w akcję obchodów Grudnia 1970, mówił w 1979 roku:

Pamiętajcie, że brak samoorganizacji społeczeństwa wobec władzy zmniejsza skuteczność naszych żądań, zmniejsza możliwość realizacji praw każdego z nas i praw narodu, pociąga za sobą ofiary, których można by uniknąć nawet wtedy, gdybyśmy żądali ich nie tu, pod bramą stoczni, lecz w płonących komitetach."

„Samoorganizacja”, ,skuteczność, ,,realizacja praw”, ,ofiary, których można by uniknąc" - to nie jest język powstania, lecz etyczny apel o podjęcie pragmatycznych działań. Z tej perspektywy Sierpień 1980, nawet jeśli dziedziczył po Grudniu 1970, był wielkim eksperymentem, który rozwijał się, wychodząc poza ramy pamięci.

W rozmowach, które w styczniu 1981 roku Ireneusz Krzemiński przeprowadził z twórcami niezależnych związków zawodowych, pamięć - w postaci implikowanej czy stematyzowanej - pojawiała się bardzo rzadko. Kluczową rolę w zakładaniu związków odgrywały niepełna wiedza aktualna, wyobraźnia, improwizacja, tempo:

1 IX poszliśmy do dyrektora i powiedzieliśmy, że zakładamy związki niezależne. 5 IX pokazaliśmy dyrektorowi statut „Mazowsza”.12 Cała sprawa polegała na tym, że od samego początku nie było wiadomo, czy porozumienie podpisane w Gdańsku dotyczy samego Gdańska, samego Wybrzeża, czy obowiązuje w całym kraju. [...] wszystko [czyli utworzenie Niezależnego Samorządnego Związku Zawodowego w PAN - przyp. P.Cz.] leciało w wariackim tempie, bo 1-go [września - przyp. P.Cz.] było podpisane porozumienie, a już 4-go [...] odbyło się pierwsze zebranie. ${ }^{13}$

Wszystko rodziło się niesamowicie spontanicznie $[\ldots]^{14}$

\footnotetext{
11 Cyt. za: M Zaremba „Im się zdaje, że zapomnimy. O nie!"...

12 I. Krzemiński Solidarność..., s. 47.

13 Tamże, s. 47.

14 Tamże, s. 48.
} 
Takich wypowiedzi można przytoczyć dziesiątki. Najmniej istotne są w nich historyczne porównania czy pamięciowe zestawienia. To, co się działo, czerpało logikę z wielu źródeł, ale łączyło je w nowy nurt. W rezultacie „Solidarność" jawi się jako zbiorowe zadanie wymyślenia i wypracowania historycznej różnicy. Różnica ta, czyli nowa metodyka działań zbiorowych, powstała w trzech fazach: strajku okupacyjnego, komitetów międzyzakładowych i struktury ogólnokrajowej. Strajk nawiązywał do tradycji walk proletariatu z kapitalizmem, komitety międzyzakładowe czerpały z dziedzictwa proletariatu komunistycznego, zaś sieć krajowa - przypominająca rady robotnicze na Węgrzech roku 1956 - tworzyła antymodel państwa ${ }^{15}$. Sieć ta była systemem powiązań wszystkich członków i komitetów, a zarazem demokratycznym mechanizmem wyłaniania delegatów upoważnionych do prowadzenia rozmów z władzami i do podejmowania decyzji. Rozszerzanie „Solidarności” prowadzono tak, aby zasady demokracji bezpośredniej pogodzić z republikańskim porządkiem przedstawicielskim.

Uczestnicy ruchu byli zatem świadomi znaczącej różnicy między dwoma typami demokracji: samodzielnie wypracowali praktykę, która minimalizowała alienacyjne skutki delegowania władzy na innych i która zobowiązywała delegatów do konsultowania się z radami i kolektywem. Nie dyktowała tych rozwiązań ani pamięć powstań, ani imperatyw buntu. Rację ma Bronisław Świderski - autor jednej z najważniejszych analiz „Solidarności” - gdy pisze:

Sposób zorganizowania i działania tego związku był pierwszym, na tak wielką skalę, nieinsurekcyjnym, czytaj: nieromantycznym, wysiłkiem polskiego społeczeństwa w ciągu ostatnich 200 lat. „Solidarność" była organizacją demokratyczną, bo łączyła przestrzeganie obowiązującej konstytucji, gwarantującej obywatelom wolność „sumienia i religii” (art. 82), wolność „słowa, druku, zgromadzeń" (art. 83) oraz prawo do zrzeszeń (art. 84) z uznaniem tych uprawnień za prawa naturalne, niezależne od interesów państwa. "Solidarność" była także organizacją demokratyczną, bo programowo nie stosowała przemocy, traktując tradycję romantycznego powstania jako metaforę polityczną, a nie jako instrukcję strategiczną. ${ }^{16}$

15 Koncepcja "Solidarności” jako „antymodelu państwa” - zob. R. Laba The Roots of Solidarity. A Political Sociology of Poland's Working-Class Democratization, Princeton University Press, Princeton 1991, S. 113. 
Dopiero w oficjalnych oświadczeniach, formułowanych ze świadomością wywalczonej różnicy i niepewności dalszego ciągu, społeczne pamiętanie sięgało do wcześniejszych buntów i powstań:

społeczny i moralny protest [roku 1980 - przyp. P.Cz.] nie zrodził się z dnia na dzień. Jest w nim dziedzictwo krwi robotników poznańskich z 1956 roku i grudnia 1970 na Wybrzeżu, bunt studentów w 1968 roku, czerwiec Radomia i Ursusa w 1976 roku. Jest w nim dziedzictwo niezależnych działań robotników, inteligencji i młodzieży, wysiłków Kościoła o przechowanie wartości, dziedzictwo wszystkich walk o godność ludzką w naszym kraju. Związek nasz wyrósł z tych walk i pozostanie im wierny. ${ }^{17}$

Widzimy w tym dokumencie, jak pamięć zbiorowa bez trudu - z lojalnością wobec buntów wcześniejszych, z dumą, że wstępuje się w ślady poprzedników - wyznacza i wzmacnia linię własnej tradycji.,,Protest”,,,krew”,,,bunt” to słowa, które osadzają "Solidarność” w tradycji walki i gotowości ponoszenia ofiar. Zarazem w tym samym oświadczeniu pojawiło się pojęcie "godności", które kierowało w inną stronę - porozumienia, szacunku, kompromisu, dia$\log \mathrm{u}^{18}$. Pojęcia te tworzyły w roku 1980 nowy leksykon historii. Za ich sprawą zamiast powstańczej alternatywy „dziś twój triumf albo zgon" wyłaniała się koncepcja inkluzywna - uwzględniająca "godność" (warunków życia) jako wartość równie istotną co wolność i nakazującą szukać innych rozwiązań niż „śmierć za ojczyznę". Dążenie do porozumienia implikowało myślenie długofalowe, oparte na włączaniu kolejnych podmiotów w sieć współdziałania, otwarte nawet dla członków partii.

Była to również inkluzywność obejmująca ustrój socjalistyczny. Ruch „Solidarnościowy” zmierzał do uspołecznienia środków produkcji i do zdemokratyzowania metod podejmowania decyzji. Centralną kategorią działań

17 Wstęp do Uchwały Programowej delegatów na Krajowy Zjazd Delegatów (AS, Biuletyn Pism Związkowych i Zakładowych, Agencja "Solidarność", 1981, nr 41).

18 Świadczy o tym np. list wystosowany 20 sierpnia 1980 roku przez intelektualistów i pisarzy środowiska warszawskiego do robotników strajkującej stoczni gdańskiej, w którym apelowano, aby drogą ustaleń była „droga rozmów, [...] droga kompromisów. [...] Wszyscy - rządzeni i rządzący musimy kierować się dobrem Polski. [...] Nauczmy się wszyscy wzajemnie szanować swoją godność" - Zapis rokowań gdańskich. Sierpień 1980, zebrali i oprac. A. Drzycimski, T Skutnik, Editions Spotkania, Paris bd., s. 213; cyt. za: B. Świderski Gdańsk i Ateny..., S. 134 . 
było pojęcie „wspólnego dobra” - w odniesieniu do rządzenia i wytwarzania. Wyraźne wskazanie na tę intencję znajdziemy w słowach Lecha Wałęsy, który komentując wydarzenia z lat 1980-1981, stwierdzał: „W socjalizmie większość warstw społecznych przywykła do pewnych jego zdobyczy, mamy już we krwi świadczenia socjalne, szpitale, szkoły. A więc krótko mówiąc, żeby socjalizm był do zaakceptowania, zastrzegliśmy, że to, co jest najlepsze w ekonomii, w kwestii świadczeń społecznych jest socjalistyczne, nawet jeśli wychodziło poza jego dotychczasowe ramy"19.

Kluczowe dla niniejszych rozważań jest właśnie owo „wychodzenie poza ramy", wynikające $z$ ustawicznego odkrywania, że ani powstanie, ani żadna inna formuła przeszła nie wystarczają do rozwiązania aktualnych sprzeczności. Pamięć zbiorowa dostarczała szczątkowych wzorców i zarazem okazywała się niedostateczna, ponieważ napotykane problemy „wychodziły poza ramy" przeszłości. Dlatego uczestnicy społecznego ruchu starali się działać tak, aby pamięć nie zdominowała teraźniejszości, a imperatyw buntu nie pokonał realizmu.

Nie chodziło o równość walki, umierania, cierpienia czy zabijania, lecz o równość współudziału w tworzeniu innego porządku życia. O odzyskanie poczucia bycia u siebie. Być może - i w tym sensie Marcin Zaremba ma rację - gdyby nie pamięć powstańcza, działacze „S” nie walczyliby o pozapragmatyczną "godność" i nie wykazaliby takiego uporu. Zarazem - i tu nasza zgoda się kończy - gdyby pamięć zbiorowa prowadząca do narodzin ruchu „S” była zdominowana przez klisze powstańcze, wówczas nie doszłoby do rozmów w Gdańsku, do dialogu strajkujących z władzą, do podpisania porozumienia, do utworzenia wolnego związku zawodowego. Kluczowe pojęcia tamtego czasu - dialog, konsultacje, porozumienie, ugoda - wyłoniły się z innych tradycji niż powstańcza albo zgoła przeciw tejże tradycji. Niezwykłe napięcie, jakie przenikało całe życie społeczne tamtego okresu, wynikało, jak można sądzić, właśnie z tego, że inwencja społeczna czerpała z pamięci rozmaite podpowiedzi, ograniczając ich stosowalność i adekwatność. Myślenie rewolucyjne hamowało skojarzenia powstańcze, a myślenie w kategoriach związku zawodowego kontrowało dążenie do utworzenia partii politycznej. Stawką nie było bowiem pokonanie wroga, lecz wymyślenie nowego modelu życia zbiorowego. 


\section{Powstanie przeciw rewolucji}

W niezliczonych analizach „Solidarność" bywa ujmowana jako rewolucja, związek zawodowy ${ }^{20}$, partia polityczna lub powstanie ${ }^{21}$. Im solidniejsze studium, tym częstsze łączenie dwóch lub trzech elementów ${ }^{22}$.

Dwie skrajne kategorie - rewolucja i powstanie - są sobie bliskie, ponieważ zjawiska, do których odsyłają, to masowe i żywiołowe, trudne do opanowania ruchy. Kategorie środkowe - związek zawodowy i partia polityczna - zbliżają się do siebie, ponieważ określają organizacje (różne pod względem celów i metod działania). Jeśli jednak ustawiłem je właśnie w tej kolejności, to dlatego, że w dziejach „S” rewolucja kierowała raczej ku związkowi zawodowemu, zaś powstanie - ku partii. W ten sposób można wyjaśnić szczególną dynamikę ruchu, który dla zrealizowania rewolucyjnych celów musiał wytworzyć związkową strukturę organizacyjną i który, po porażce dążeń do zmiany struktury władzy, zmienił się w podziemną konspirację podlegającą logice partyjnej. Ujmując rzecz inaczej: pierwszy okres „S”, obejmujący lata 1980-1981, był raczej rewolucyjny, drugi, po wprowadzeniu stanu wojennego, raczej powstańczy.

Analizy dotyczące rewolucyjności pierwszego okresu nakazują zrezygnować z czystej kategorii. Wskazują na to oksymoroniczne określenia „pełzająca rewolucja”, ,samoograniczająca się rewolucja”, „rewolucja bez przemocy” czy „ceremonialna rewolucja”. Z punktu widzenia tradycji marksowskich

20 "Solidarność" to "totalny ruch społeczny", stanowiący "połączenie akcji związkowej oraz walki o wolne związki zawodowe z ruchem na rzecz demokracji i narodowym powstaniem" (A. Touraine, J. Strzelecki, F. Dubet, M. Wiewiorka „Solidarność". Analiza ruchu społecznego 1980-1981, Bmw 1989, s. 9).

21 "[...] W wydarzeniach lat 1980-1981 można odnaleźć kilka istotnych elementów stanowiących wyraźne nawiązanie do polskiej tradycji powstańczej. Po pierwsze, ruch solidarnościowy miał ściśle określonego wroga, zaciekle broniącego starego porządku. [...] Po drugie, podobnie jak insurekcja kościuszkowska czy - w mniejszym stopniu - powstanie styczniowe, «S» miała charyzmatycznego przywódcę [...]. Po trzecie wreszcie, bardzo istotny element programu związku stanowiła idea solidaryzmu narodowego" (A. Dudek Rewolucja robotnicza i ruch narodowowyzwoleńczy, w: Lekcja Sierpnia. Dziedzictwo "Solidarności” po dwudziestu latach, praca zbiorowa pod red. D. Gawina, Wydawnictwo IFiS PAN, Warszawa 2002, S. 150-151).

22 T. Garton Ash Polska rewolucja. Solidarność 1980-1981, przeł. M. Dziewulska, M. Król, Res Publica, Warszawa 1990, s 219: „Polacy w gruncie rzeczy stworzyli oryginalną mieszankę idei zaczerpniętych z różnych tradycji. W polityce wierni byli podstawowym zasadom liberalnej demokracji, ale połączyli je z propozycjami radykalnej decentralizacji, społecznej kontroli i lokalnego samorządu, które nie istnieją na Zachodzie. [...] W dziedzinie kultury i edukacji ideały ich można najlepiej określić jako konserwatywno-restauracyjne. W sferze gospodarki pragnęli połączyć rynek, samorząd i planowanie". 
wszystkie te adiectiva stanowią sprzeczność wewnętrzną: rewolucja nie może się ograniczać, pełzać czy wyrzekać się przemocy. Właśnie jednak owe kontradykcje lepiej pozwalają zrozumieć pierwszy okres „Solidarności”, gdy dążenia związkowe, partyjne czy powstańcze spowalniały rewolucję i nadawały jej charakter pełzający.

Z tych powodów struktura własności środków produkcji nie zmieniła się, przywódcza rola partii nie zniknęła z konstytucji, a sojusze militarne i polityczne wiążące PRL z ZSRR nie zostały wypowiedziane. Jeśli mimo to wiele argumentów przemawia za tezą o rewolucyjności pierwszego okresu „S”, to ze względu na komunikację społeczną. W sferze tej nastąpiło uwłaszczenie komunikacyjne, które polegało na stworzeniu warunków dla porozumienia wielogłosowego, równego i zwrotnego, będącego podstawą zmienionych reguł uczestnictwa w podejmowaniu decyzji ${ }^{23}$. W ramach takiej komunikacji każdy miał prawo głos zabrać i każdy miał prawo domagać się odpowiedzi na zadane pytanie.

Komunikacja społeczna zmieniła się po wprowadzeniu stanu wojennego - i była to zmiana tak istotna, że przekształcała ruch rewolucyjny w ruch powstańczy. Formułując powyższe twierdzenie, przechodzę na stronę Marcina Zaremby. Jeśli jednak przyznaję mu chwilowo rację, to tylko po to, by dodać, że wpływ myślenia powstańczego odnajduję zupełnie gdzie indziej, niż on to czyni, i że wpływu tego nie uważam za zjawisko pozytywne.

Analiza języka publicznego - zwłaszcza w sferze codziennej - dostarczy nam wielu dowodów poświadczających powstańczą radykalizację nastrojów zbiorowych. Po 13 grudnia 1981 roku następuje swoista militaryzacja wyobraźni, znajdująca swoje ujście w topice powstańczej, wojennej i okupacyjnej. Na murach kamienic miejskich - które powrócą w następnej części moich rozważan - pojawiła się litera "S" wrysowana w kotwice Polski Podziemnej, a także napisy „Pamiętamy” czy przedstawienia żółwia, który w czasie okupacji 1939-1945 był równoznaczny z nakazem „Pracuj wolniej - pracujesz dla okupanta". Podczas manifestacji i ulicznych walk z milicją - odbywających się każdego trzynastego dnia miesiąca - wznoszono okrzyki „ZOMO - gestapo!", które skracały dystans między stanem wojennym i okupacją niemiecką. Równocześnie tworzono podziemne struktury „Solidarności”, prowadzono tajne kursy nauczania i tajne pokazy filmów, organizowano spotkania dyskusyjne i wieczory artystyczne, zakładano partie polityczne i stowarzyszenia,

23

Pisze o tym przekonująco Bronisław Świderski w studium poświęconym demokracji bezpośredniej (Gdańsk i Ateny..., zwł. rozdział 2: O porozumiewaniu się Polaków, s. 87-139). 
a w niezależnym obiegu wydawano kilkaset tytułów książkowych rocznie. Kultura konspiracyjna osiągnęła poziom rozwoju porównywalny z aktywnością podziemną czasów okupacji.

Zarazem właśnie ta powstaniowa militaryzacja wyobraźni przekształcała reguły komunikacji społecznej. Wcześniej zarysowana przeze mnie rewolucja polegała na dążeniu do wypełnienia sfery politycznej przez komunikację zwrotną, zróżnicowaną i równą. Po 13 grudnia 1981 roku funkcjonowała ona nadal, ale w aktach spazmatycznych - podczas ulicznych zajść. Natomiast konspiracja, która zyskiwała legitymizację tylko jako przygotowanie do przyszłego powstania, zatwierdzała komunikację jednokierunkową, monologową i hierarchiczną, minimalizującą dialog i samodzielność. W połowie lat 80. Adam Michnik w książce Takie czasy ${ }^{\mathbf{2 4}}$ nie diagnozował nowych podziałów społecznych, lecz ostrzegał przed autorytarnymi ambicjami lokalnych przywódców „S" i sugerował, by uznać doradców „S” za jedynych reprezentantów społecznego ruchu. Syndrom konspiracyjny kierował zatem ku centralistycznemu kształtowaniu komunikacji.

Powstanie - rozumiane tak, jak pojmuje je Marcin Zaremba, a więc jako polska tradycja kulturowa - pojawia się tu nie jako „czyn”, lecz przede wszystkim jako struktura wyobrażeniowa porządkująca rzeczywistość. Decyduje ona o sposobie postrzegania i kształtowania relacji społecznych. W latach 8o. relacje owe upodobniały strukturę społeczną do struktury militarnej z odległym dowództwem, tajnym przepływem rozkazów w dół, nieistotnością dialogu i powszechnością niejawnej, acz jednomyślnej przynależności do oddziałów. W ramach tego podziału - na elitarne jednostki decyzyjne i egalitarne masy aktywistyczne - „dowództwo” kierowało apel ku masom, by te wyszły na ulice wywrzeć nacisk na reżimowe władze, które ustąpią i zgodzą się złagodzić konkretne przepisy bądź, tak przedstawiał się cel ostateczny, zasiądą do rozmów z opozycją. W ten sposób logika powstańcza lat 80. przygotowała grunt pod rozmowy Okrąłłego Stołu i pod demokrację przedstawicielską, czyli taką, w której obywatele wypowiadają się we własnych sprawach raz na cztery lata, cedując decyzyjność na swoich delegatów.

Przez całą dekadę - od stanu wojennego do wyborów kontraktowych roku 1989 - społeczeństwo symulowało insurekcję, zmuszając władze do kolejnych ustępstw. Zarazem w ramach owej symulacji nie stawiano pytań kluczowych - o przyszłą własność środków produkcji i komunikacji, o udział w sprawowaniu władzy i w jej kontrolowaniu. Im skuteczniej odgrywano

24 A. Michnik Takie czasy, NOWa, Warszawa 1985, zWł. s. 26-31. 
powstanie, które nigdy nie miało wybuchnąć, tym bardziej malały szanse na wspólne negocjowanie nowego kontraktu dziejowego. Jeśli w latach 8o. toczyło się powstanie, to z pewnością masy go nie wygrały.

Konspiracyjno-powstańcza wyobraźnia, która zdominowała kulturę polityczną lat 80., decydowała również o podtrzymaniu podziału płciowego. Nie było to zjawisko nowe, jako że pamiętny napis - „Kobiety - idźcie do domu, my tu walczymy o Polskę" - zawisł na murze stoczni gdańskiej w sierpniu $1980 \mathrm{roku}^{25}$. Konserwatywnego postrzegania dymorfizmu płciowego i jego społecznych konsekwencji nie zmienił fakt, że strajk gdański wybuchł m.in. w obronie Anny Walentynowicz i że we wszystkich strajkujących kolektywach znaczący procent stanowiły kobiety. W trakcie półtorarocznego okresu wolności kobiety nadal były postrzegane jako „strażniczki domowego ogniska" i jako osoby, które z powodu uwarunkowań biologicznych nie powinny brać udziału w życiu publicznym. Trwał zatem patriarchalny protekcjonalizm, lokujący kobiety poza sferą „męskiej walki” o władzę i znaczenie.

Stan wojenny wzmocnił to myślenie, dodając do niego militarno-powstańcze uzasadnienie. Kiedy społeczeństwo domagało się wolności dla Polaków, uniwersalne określenie „Polacy” kamuflowało męską płeć reprezentanta ogółu. W rezultacie przestrzeń społecznie istotna znalazła się w stanie trwałej i etycznie wątpliwej schizofrenii: po wprowadzeniu stanu wojennego, a więc po internowaniu ponad pięciu tysięcy mężczyzn, podziemie funkcjonowało przede wszystkim dzięki kobietom, ale system konspiracyjno-powstańczej wyobraźni czynił kobiety niewidzialnymi ${ }^{26}$.Tymczasem bez kobiet „nie byłoby doradców TKK, «Tygodnika Mazowsze», regionu, poznańskiego radia ani sieci kontaktów społecznych. Nie byłoby łączniczek, maszynistek, mieszkań, nie miałby kto robić zakupów dla ukrywających się działaczy. Kobiety albo nadal robiły to samo, czym zajmowały się przedtem, albo zainicjowały całkiem nowe formy oporu. Organizowały latające redakcje i nieformalne grupy, kierowały nimi, pracowały w nich. Do 1988 roku dwie kobiety, Ewa Kulik i Barbara Labuda, zostały przedstawicielkami swoich komisji regionalnych. [...] jednak przyjęty przez ruch system wartości nie uległ zmianie i nie uwzględnił zachodzących przemian. Działania były szybsze niż rozwój

25 Pisze o tym Agnieszka Graff - zob. tejże Świat bez kobiet. Płeć w polskim życiu publicznym., W.A.B., Warszawa 2001. 
myśli teoretycznej. Nie doszło więc do zmiany systemu wartości, w którym doceniono by istotny wkład kobiet"27.

Podział na „my - oni”, wzmocniony przez poczucie obcości wobec ustroju i rządu, skutecznie blokował myślenie autokrytyczne i nie pozwalał zobaczyć, jak wiele władzy, symbolicznej przemocy i codziennego wyzysku skrywa się w relacji „mężczyźni - kobiety”. Rewolucja „Solidarnościowa” miała, a przynajmniej mogła, wnieść do owej relacji znaczące zmiany. Stan wojenny zakonserwował powstańcze wyobrażenie o doniosłości męskiej roli i konieczności siłowego udziału w historii. Przyniosło to fatalne skutki dla porządku demokratycznego w III RP: przy Okrągłym Stole wśród sześćdziesięciu opozycjonistów znalazła się tylko jedna kobieta, a w 1993 roku zlikwidowano Komisję Kobiet i zaostrzono ustawę antyaborcyjną. Władza po roku 1989 okazała się władzą rodzaju męskiego: wywłaszczyła kobiety z podmiotowości i uczyniła z ciała kobiecego przedmiot politycznego przetargu. Jeśli w latach 8o. trwało powstanie, to z pewnością kobiety go nie wygrały ${ }^{\mathbf{2 8}}$.

\section{Piąty żywioł}

Na początku stycznia 1982 roku na murze jednej z poznańskich kamienic pojawił się napis: „Zima wasza, wiosna nasza”. Zdanie proste i genialne: rytmiczne, logiczne, wymowne. Zapowiedź zwycięstwa wiązała się tu z porami roku, kierując skojarzenia czytelników naściennego hasła ku cykliczności kalendarza przyrodniczego. Bunt wybuchnie tak, jak wybucha kwitnienie; społeczeństwo weźmie w posiadanie wiosnę i pokona tych, którzy w przymierzu z zimą zaaresztowali Polskę. Zapowiedź, profecja i groźba w jednym doskonale wzmacniały też klarowny podział na „wy” i „my”. Władza stoi po stronie zimy, zamierania, przestoju; zwycięża nie tyle siłą własną, ile dzięki sojuszowi z mrozem, który zatrzymuje ludzi w domach. „My” ma za sobą rację życia; stoi po stronie światła, rozwoju, wzrostu, więc owo „my”, chwilowo

27 S. Penn Podziemie kobiet, przeł. H. Jankowska, wstęp M. Janion, Rosner \& Wspólnicy, Warszawa 2003, s. 160-161.

28 M. Janion Ifigenia w Polsce, w: tejże Kobiety i duch inności, Sic!, Warszawa 1996, s. 326-327: „[...] pod koniec lat 80-ych utrzymywałam, że «Solidarność» najpierw musi wywalczyć niepodległość i demokrację dla całego społeczeństwa, a potem dopiero będzie mogła spokojnie zająć się kwestią kobiecą i polepszeniem kondycji kobiet No, i zajęła się, z wiadomym skutkiem, odsyłając kobiety do ich tradycyjnego sposobu życia nie jako jednostek ludzkich, lecz jako «istot rodzinnych» i uchwalając represyjne postanowienia w kwestii aborcji. Trochę czasu upłynęło, zanim pojęłam, że «demokracja w Polsce jest rodzaju męskiego»" [wyr. w tekście]. 
nieobecne w przestrzeni wspólnej, wyjdzie z domów i zwycięży tak, jak kiełkowanie i wzrost pokonują zmarzniętą glebę.

Wiosna roku 1982 nadeszła, układ sił się nie zmienił. W czerwcu ktoś uzupełnił hasło, które w nowej wersji brzmiało: „Zima wasza, wiosna nasza, lato muminków".

Na prawach wielkiego skrótu można uznać ten dopisek za doniosły moment w dziejach społecznej komunikacji lat 8o. Oto bowiem zamrożona dychotomia „oni - my" ulegała wzbogaceniu: ostatnia część napisu nie pochodziła ani od władzy, ani od „Solidarności”. Jej nadawcą był ktoś trzeci - ktoś, kto nie mieścił się w binarnej logice, jaka zdominowała myślenie i mówienie po wprowadzeniu stanu wojennego. Ten trzeci uczestnik nie dysponował swoim językiem ani nie przemawiał w imieniu wyraźnej grupy społecznej. To różniło go od dwóch pozostałych podmiotów komunikacji. Pojemne „oni” odsyłało do władzy, reżimu, Moskwy, Azji, komuchów, zdrajców, gestapowców, sowietów; jeszcze obszerniejsze „my” oznaczało „prawie wszystkich” - społeczeństwo, Polaków, „Solidarność, naród. Ten Trzeci był niczyj i przychodził nie wiadomo skąd, ale jego pojawienie się w przestrzeni publicznej sygnalizowało coś więcej niż potrojenie; burzyło przekonanie, że podział „oni - my" jest kompletny, że pokrywa bez reszty mapę społeczną, że wyczerpuje listę możliwych identyfikacji.

Żartobliwy dopisek był też sygnałem, że Ten Trzeci nie ma swojego języka. W odróżnieniu od zideologizowanego języka władzy, wąskiego idiomu kłamstwa i cynizmu, a także w odróżnieniu od bogatego języka "my" - pełnego podniosłych haseł, frazesów, moralnych racji, mądrych teorii, bogatych tradycji - język Trzeciego istniał zaledwie domyślnie, jako tradycja pozbawiona wyrazistego szacunku społecznego. „Muminki”, choć powszechnie znane, nie były zaliczane do archiwum prawomocnej kultury, z której można by czerpać narzędzia potrzebne do moralno-merytorycznej walki z reżimem. Trzeba było niejakiej odwagi, aby wejść z muminkami między zwalczające się strony. Taktyka filipa z konopi sygnalizowała właśnie odpatetyzowanie walki językowej: stan wojenny przez jego zwolenników był przedstawiany jako ratunek przed wojną domową, a przez jego krytyków jako „wojna z narodem”, zabór, Sybir bądź okupacja. Dopisanie „lata muminków” do „wiosny (ludu)" pozwalało dostrzec zarówno język sporu, jak i fikcyjność stojących za nim podmiotów. Ludyczny dodatek zmieniał całość. Żart był bronią przed rozpaczą, ale także chłodził wiarę w magię słów.

Kiedy lato 1982 roku dobiegało końca, na murze pojawiła się czwarta część napisu. Teraz brzmiał on: „Zima wasza, wiosna nasza, lato muminków, jesień 
średniowiecza". Gra toczyła się więc dalej - dynamiką niezależną od retorycznej walki władzy z Solidarnością. Kolejne osoby i grupy sytuowały się coraz dalej od centrum sporu.

Czy nowi uczestnicy komunikacji społecznej pojawili się dopiero po stanie wojennym? Nie sądzę. Ten Trzeci, dodający jedną pozycję nadawcy do dychotomicznej debaty i zarazem otwierający horyzont na ich nieskończoną mnogość, właśnie za sprawą dowcipu uświadamiał, że historia komunizmu to także historia komizmu. W niezliczonych odmianach - ulicznej, graficznej, drukowanej, śpiewanej, kabaretowej - istniał nawet w gorszych, hitlerowskich czy stalinowskich czasach. A istniejąc, podważał każdą koncepcję ujednolicenia, obojętnie kogo miałaby ona dotyczyć - społeczeństwa, historii czy władzy.

Komizm ten działa jak piąty żywioł. Nie należy do żadnego z istniejących porządków, bo choć każdemu coś podkrada, wobec żadnego nie czuje się dłużny. Reaguje na grozę i zwykłą oficjalność, mierzy w osoby i sytuacje, rodzi się z zakrzepłych języków i rytuałów. Nie szanuje niczego, przemawiając w imieniu resztki, która bywa milczącą większością. Chciałby więcej życia, dlatego świętuje nieoficjalność; pochwala swobodę, więc ośmiesza praktycyzm; sprzyja niespodziance, krzywi się więc na wszelkie plany i porządki. Jest aktywny, rodząc się sam z siebie, i reaktywny - wulgarny w odpowiedzi na przymusową grzeczność, drapieżny w reakcji na pozory łagodności, rubaszny i sprośny w świecie salonowym. Nie ma reguł, prócz zasady słownego nieposłuszeństwa.

Jeśli prześledzimy wyłącznie ruch społeczny, z którego wyłoniła się „Solidarność", zauważymy, że humor istniał tam równolegle i równocześnie z wszelkimi poważnymi inicjatywami. Funkcjonował jako autokorekta, jako narzędzie powstrzymujące przed znieruchomieniem w moralnej powadze, w mesjańskiej jedności, w misyjnej pozie. Ośmieszał absurdy socjalizmu, ale kpił też z powstańczej frazeologii. Białoszewski przypominał zatem, że padanie na kolana i pochylanie „głowy do podłogi” uwydatnia „wypiętą antygłowę"29, czyli zadek. Tadeusz Ross w piosence z pamiętnym refrenem „Wejdą, nie wejdą...", sparafrazował Pana Tadeusza, artykułując powszechny lęk przed wkroczeniem wojsk radzieckich do Polski i przemieniając ów strach w rubaszny dowcip o Zosi, kocyku i mrówkach. A wreszcie tę samą komiczną niestosowność, hamującą przemianę zwykłości w patos, można było odnaleźć

29 M. Białoszewski Wybuch stanu, w: tegoż "Oho" $i$ inne wiersze opublikowane po roku 1980, PIW, Warszawa 2000, s. 213. 
w pamiętnym geście Wałęsy, który w historycznej chwili podpisywania porozumień gdańskich posłużył się wielgachnym długopisem.

Czymkolwiek był ruch „Solidarnościowy”, ożywiana w jego trakcie pamięć formularna - podsuwająca wzory zbiorowego przeżywania jedności - była nieustannie kontrowana przez wywiedziony z tradycji kulturowych imperatyw komiczny. Dowcip, który kwitł w epoce Gierka, eksplodował po Sierpniu. Było go coraz więcej - w gazetkach, na pirackich kasetach, w pojedynczych skeczach i programach kabaretowych, w rysunkach, piosenkach i ulicznych kawałach. Występował jednak nie tylko jako broń w walce z reżimem, lecz także jako zbawienna kpina z poczucia niezachwianej słuszności własnej. Nie przypadkiem Miron Białoszewski w jednym z pierwszych odcinków Kabaretu Kici-Koci napisał: „Korzystam z wolności słowa / Kochani! Kochane! / Oddzielność się skończyła. / Zabija nas bezustanna bomba łańcuchowa społeczności" ${ }^{\prime \prime}$, żartobliwie ostrzegając przed jednością, która może tłumić - kluczową dla autora - pojedynczość.

Pełna ludowej adoracji i dziecięcej niestosowności poetyka kabaretu Białoszewskiego z każdym miesiącem stanu wojennego okazywała się coraz trudniejsza i rzadsza. Komizm po grudniu 1981 roku tężał, zamieniając się w sarkazm, gorzką ironię przegranych, paszkwil ${ }^{31}$. Jeśli pamięć sugerowała podobieństwo rewolucji „Solidarnościowej” do narodowych powstań, to stan wojenny musiał kojarzyć się z okresami popowstaniowymi - z epoką Paskiewicza, z kolaboracją, powszechnym znijaczeniem. Właśnie dlatego, że sytuacja ulegała radykalnemu uproszczeniu, komizm stawał przed zadaniem rozszczepiania dyskursów, odnajdywania wielości w dychotomii, wytrącania z powagi. Z tych właśnie powodów obieg niezależny po stanie wojennym wydając Króla Ubu Jarry'ego, Trans-Atlantyk Gombrowicza, Folwark zwierzęcy Orwella - reinterpretował modernizm, „zdecydowanie dowartościowując teksty komiczne"32.

Ten typ komizmu, przekłuwającego balony narodowego patosu, można odnaleźć u samych początków kultury niezależnej. Jego tradycje odświeżał

M. Białoszewski Odczyt Kici-Koci, w: tegoż „Oho"i inne wiersze..., s. 210.

Poetykę paszkwilu, istotną tradycję komunikacji podziemnej po 13 grudnia 1981 roku, zapowiadał jeden z najgłośniejszych tekstów o takim charakterze - czyli wymierzony w postawy kolaboranckie Gnidzi parnas Piotra Wierzbickiego (NOWa, Warszawa 1980).

T. Mizerkiewicz „Sytuacja jest groźna, ale nie poważna” - komizm w literaturze drugiego obiegu, w: tegoż Nić śmiesznego. Studia o komizmie w literaturze polskiej XX i XXI wieku, Poznań 2007, s. 268. 
„Puls" - pismo redagowane przez Jacka Bierezina, Witolda Sułkowskiego i Tomasza Filipczaka, w latach 1977-1981 wydawane przez NOWą, a od 1982 roku w Londynie przez Jana Chodakowskiego. Jeśli „Zapis”, najpoważniejsze czasopismo literackie pierwszego okresu kultury niezależnej, był alternatywą obiegu oficjalnego, to „Puls” był alternatywą alternatywy, drugim obiegiem drugiego obiegu. Bronił przed cenzurą oficjalną i nieoficjalną, stając po stronie niezależności ekspresji3 ${ }^{33}$. Jeśli „Zapis” sięgał do tradycji polskiej powieści realistycznej i politycznej - do Prusa, Żeromskiego, Kadena - to „Puls” wybierał Gombrowicza i powieść postmodernistyczną. „Zapis” cenił powagę, "Puls” - groteskę. „Zapis” walczył z propagandowym kłamstwem, stając po stronie prawdy, „Puls” pojedynkował się z socjalistyczną kulturą masową i praktykował wielość prawd. Dlatego w pierwszym numerze „Pulsu” redakcja opublikowała bulwersujące obyczajowo wiersze Antoniego Pawlaka, skandalistę epoki kontrkultury (Ginsberg) i antyheroiczną, błazeńską, absurdalną groteskę powieściową pt. Dysiek Sułkowskiego.

Do tej taktyki - innej niż jednostronna satyra wymierzona w ustrój czy władze ${ }^{34}$ - nawiązywała Pomarańczowa Alternatywa. „Pomarańczowi” czerpali z tradycji holenderskich Provosów, francuskiego sytuacjonizmu i polskich manifestacji ulicznych ${ }^{35}$. O ich oryginalności zadecydował niecodzienny wybór odwagi bycia śmiesznym - nieznanej zarówno władzy, jak i „Solidarności". Wymagała ona zastosowania innej taktyki - nie powstańczej, opartej na gotowości prowadzenia walki, nie konspiracyjnej, wymagającej zakrycia tożsamości, lecz kampowej, której punktem wyjścia było czułe, cudownie wieloznaczne, niewiarygodne z punktu widzenia władzy wyznanie wiary w socjalizm: „Pomarańczowa Alternatywa to był chyba jedyny przypadek, kiedy odważyliśmy się cofnąć do własnego dzieciństwa i przemówić językiem socrealistycznych baśni i tego jedynego w swoim rodzaju campu, który cechował rodzime podróbki zachodnich filmów i piosenek"36. Na ulicach Wrocławia, Łodzi, Katowic pojawiały się więc tłumy przebrane za krasnoludki.

33 Niezależność najwięcej kosztuje. Relacje uczestników opozycji demokratycznej w Łodzi 1976-1980, IPN, Łódź 2008 (tu - relacje Tomasza Filipczaka, Zdzisława Jaskuły, Bartosza Pietrzaka i Ewy Sułkowskiej-Bierezin).

34 Zob. np. Szopki satyryczne 1982-1983, Wydawnictwo "Słowo" [b.d.m].

Zob. Ł. Kamiński Krasnoludki i żołnierze. Wrocławska opozycja lat osiemdziesiątych, „Pamięć i Przyszłość" 2008 nr 2, s. 7-19.

36 A. Bielik-Robson Straceni inaczej. Dziwnitrzydziestoletni i ich kłopoty z samookreśleniem, w: Wojna pokoleń, red. P. Nowak, Prószyński i S-ka, Warszawa 2006, s. 62. 
Uczestnicy happeningów nie wznosili wrogich okrzyków, nie rzucali kamieniami, czcili natomiast najbardziej znienawidzone święta - Dzień Milicjanta czy rocznicę Rewolucji Październikowej - wprawiając w osłupienie służby porządkowe i wpędzając w konsternację przedstawicieli władz. W połowie lat 8o. nikt - z partią na czele - nie wierzył w socjalizm, choć propaganda nie pozwalała tego wyznać. Pomarańczowa Alternatywa, wyznając miłość do realnego socjalizmu - jako producenta najbardziej nierealnej rzeczywistości - wciągała władze w pułapkę złych wyborów: aresztować ludzi świętujących Dzień Milicjanta, znaczyło przyznać, że jest to święto pozorne, a pozwolić ludziom bawić się na ulicy, znaczyło przyznać, że społeczeństwo samodzielnie definiuje sytuację $e^{37}$.

Krasnoludkowy dowcip nie wytrącał uzbrojonym broni z ręki, ale obezwładniał dyskurs władzy i unieważniał podział na "dzielne społeczeństwo” i „niemoralny reżim”. Happeningi - podczas których rozdawano papier toaletowy czy podpaski higieniczne, wznoszono okrzyki „Nie ma wolności bez krasnoludków!" czy biegano wokół rynku dla zobrazowania określenia "Galopująca inflacja" - wciągały wszystkich w wir śmieszności: uczestników ubranych w czerwone czapeczki, władzę wysyłającą groźnych milicjantów do pacyfikowania krasnoludków, a także „powstańcze masy” szykujące się do kolejnej manifestacji pod hasłem „Precz z komuną!”.W przestrzeni wypracowanej przez Pomarańczowych - tyleż wspólnej, co niepodlegającej normalnym regułom, tyleż zagrożonej interwencją milicji, co eksterytorialnej - pojawiała się na moment zbiorowość ludzi równych.

Pierwsza faza „Solidarności” proponowała rewolucyjną równość ludzi godnych, chcąc doprowadzić do stworzenia warunków egalitarnego udziału w sferze decyzyjnej. Faza druga, wyłaniająca się po klęsce rewolucji, ograniczyła się do powstania niepodległościowego; oferowało ono równość na podłożu narodowym, ale nie pozwalało zobaczyć wykluczeń dotykających kobiety, osoby nieheteroseksualne czy członków klas uboższych. Pomarańczowa Alternatywa, niczym patafizyczne zwieńczenie heglowskiej dialektyki dziejowej, ogłaszała równość w śmieszności. Krasnoludkowa rebelia osadzała bunt w sferze życia codziennego, przywracając ludziom pamięć ich zwykłości. Nie była to alternatywa ani dla wyobraźni rewolucyjnej, ani dla wyobraźni powstańczej, lecz chwilowe zwycięstwo karnawału, który na kilka godzin zawiesza historię.

37 Zob. W. "Major" Fydrych, B. Misztal, Pomarańczowa Alternatywa Rewolucja Krasnoludków, Fundacja „Pomarańczowa Alternatywa”, Warszawa 2008. 


\section{„Solidarnośćc, władza, pamiętanie}

Po roku 1989 kolejne rządy stosowały własne polityki pamięci, wykorzystując doświadczenie „Solidarności” do legitymizowania demokracji pluralistycznej, transformacji neoliberalnej czy dekomunizacyjnego uzdrowienia III RP. Równolegle kolejne władze związkowe sięgały do własnego archiwum, by pod hasłami „Solidarności” walczyć o dalszą delegalizację aborcji czy wprowadzenie do konstytucji preambuły z wyznaniem wiary. Jak z tego wynika, pamięć „Solidarności” - pamięć jej ówczesnych uczestników i późniejszych interpretatorów - zawsze jest zagrożona instrumentalizacją ze strony kultury prawomocnej, dyskursu medialnego czy rządów wspieranych przez sojusze kościelno-partyjne. Najlepszym tego dowodem jest fakt, że „Solidarność”, konserwatywny pod względem obyczajowym ruch, który walczył o demokrację bezpośrednią i samorządność, o własność społeczną i decentralizację, może być dzisiaj pamiętany jako prawicowo-katolickie powstanie narodowe.

Dlatego warto, jak sądzę, rozpatrywać pamięć jako narzędzie legitymizacji oporu przeciw władzy. Formą władzy jest dziś - coraz bardziej jawne - ingerowanie w pamięć o pamięci, a więc w kształtowanie przeszłości. Bo „kto kontroluje przeszłość, ten decyduje nie tylko o kształcie przyszłości, lecz także o tym, kim mamy być" ${ }^{38}$. W książce Voices of Collective Remembering James V. Wertsch ${ }^{39}$ pisał, że pamięć zbiorowa to dynamiczna wielość głosów, którymi posługują się członkowie społeczeństwa. Specyfika owej dynamicznej wielości polega na tym, że dochodzi ona do głosu i wkracza w przestrzeń publiczną wyłącznie poprzez komunikację; z tej perspektywy "pamiętać” to nie tyle „wiedzieć, że coś istniało”, ile „komunikować, że istniało”. Dlatego nie istnieje według Wertscha statyczna "pamięć", istnieje natomiast procesualne pamiętanie.

Dla rozważań o „Solidarności” wynika z tego dość proste pytanie: jak badać tamtą pamięć, aby dobiegającego z przeszłości wielogłosu ludzi upierających się przy większej równości w podejmowaniu decyzji, wielogłosu zasługującego na usłyszenie i odpowiedź, nie zamienić w głos jeden i dominujący? Dopóki uwzględniamy tamtą wielość, utrudniamy władzy instrumentalne użycie przeszłości. Ponadto, zachowując lojalność wobec tkwiących w dziejach „Solidarności” mnogich idei sprawiedliwszego życia, wydobywamy

38 D. Middleton, D. Edwards Introduction, w: Collective Remembering, ed. by D. Middleton, D. Edwards, Sage, London-Newbury Park-New Delhi 1990, s. 10.

39 Zob. J.V. Wertsch Voices of Collective Remembering, Cambridge University Press, Cambridge 2002. 
z przeszłości warunki rozumienia siebie dziś. Być może o to właśnie chodzi: nie o krótką czy długą pamięć, ale o kolejną szansę samowiedzy.

\section{Abstract}

\section{Przemysław Czapliński}

ADAM MICKIEWICZ UNIVERSITY (POZNAŃ)

Revolt in the Framework of Memory: 'Solidarity,'Revolution, Rebellion

Entering into dialogue with M. Zaremba, Czapliński argues that the collective memory of the Solidarity movement (an aggregate of knowledge about the past and a search for justifications for current activities) was produced and reproduced; the dynamic supported revolutionary efforts in the period 1980-1981 (when memory turned out to be insufficient) and rebellious activities in the period from 13 December 1981 through 1989 (when the matrix of revolt suggested misguided solutions). Czapliński looks for the differences between these two periods not in the ideals that were proclaimed, but in the forms of communication that were elaborated - inclusive in the first period, hierarchical in the second. An important factor in'S' memory, according to Czapliński, is the'comical imperative' that undermined both the official language and the pathos of the opposition's activities.

\section{Keywords}

collective memory, rebellious frameworks of memory, revolt against memory, revolution, rebellion, comical imperative 